\section{APLS at APSA}

The Association for Politics and the Life Sciences will present five panels at the American Political Science Association meeting in Denver, Thursday, September 2 to Sunday, September 5, 1982. The APLS business meeting will be held Friday, September 3 at 12:30 PM.

\section{Program}

Panel 1: Evolution, Ethology, Sociobiology, and Politics

Chair:

Samuel M. Hines, Jr.

College of Charleston

Papers:

Empirical Evidence for a Cybernetic Theory of Politics

Peter Corning

Stanford University

Evolution and Political Thought

Joseph Losco

Widener University

The Functioning and Dysfunctioning of Political Institutions and the Human Organism

Dov Ronen

Harvard University

The Drive for Dominance: S. Herbert and the Politics of Immortality

Ray Geigle

California State College,

Bakersfield

Discussants:

Richard Hartigan

Loyala University

Odelia Funke, Environmental

Protection Agency
Panel 2: Public Policy and Biological Technologies

Chair:

James N. Schubert

Alfred University

Papers:

Political Impacts of Life-Extending Technologies

James N. Schubert

Alfred University
Legal Issues in Bio-Medical
Research and Technology
Robert Blank
University of Idaho

To Regulate or Not to Regulate: The Continuing Controversy over Genetic Engineering and Biotechnology

Samuel M. Hines

College of Charleston

Discussants:

Thomas C. Wiegele

Northern Illinois University

Raymond Zilinskas

Office of Technology Assessment

Panel 3: Research Methods and the Life Sciences

Chair:

Albert Somit

Southern Illinois University

Papers:

Cognitive Psychology and the Study of Politics

Steven A. Peterson

Alfred University

Robert Lawson

Alfred University

Ethological Methods for Analyzing Interaction Process in Small Group Legislative Decision-Making

James N. Schubert

Alfred University
Linguistic Conflicts: Why Need We Consider Neurophysiological Factors Jean Laponce

The University of British Columbia

Discussant:

Meredith W. Watts

University of Wisconsin-

Milwaukee

Panel 4: Graduate Student Panel

Chair:

Joseph Losco

Widener University

Papers:

The Politics of Hard Cases: Emerging

Structures in Bioethical Deci-

sion-Making

Thomas C. Shavory

University of lowa

A Biobehavioral Approach to Group Behavior

Mark Emmert

Syracuse University

How "Significant State Interests" Affect the Minor's Right to Abortion

Barbara Ryan

Temple University

Discussants:

Robert Blank

University of Idaho

Albert Somit

Southern Illinois University

Panel 5: Dialogues on Biology and Politics

Chair:

Thomas C. Wiegele

Northern Illinois University

Paper:

The Evolution of Political Science

Glendon Schubert

University of Hawaii at Manoa 


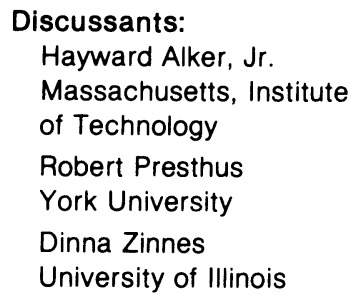

Psychophysiological Influences on Political Behavior

Chair:

$$
\text { Glendon Schubert }
$$

University of Hawaii

\section{Papers:}

Neurophysiology and Rationality in Political Thinking

Steven A. Peterson

Alfred University

\section{Hemispheric Lateralization and Political Communication \\ William Kitchin \\ Loyola College of Baltimore} What Contribution Biology?

Denise L. Baer

Southen Illinois University

David A. Bositis

George Washington University

Discussants:

Samuel M. Hines

College of Charleston

Joseph Losco

\section{Mainstream Panel:}

The Political Socialization of Gender:

Widener University

vancement of Science, a symposium entitled "Ethological Approaches to the Study of Politics" was organized by Albert Somit, president of Southern Illinois University, and Roger Masters, professor of government at Dartmouth College.

\section{Program \\ Chair: \\ Albert Somit \\ Southern Illinois University}

Papers:

Ethological Methods in the Study of Basic Types of Political Behavior

Carol Barner-Barry

University of Maryland

Baltimore County

Biological Correlates of Social Status Changes in Verbet Monkeys

Michael T. McGuire

University of California

at Los Angeles

Nice Guys Don't Finish Last: Aggressive and Appeasement Gestures in Media Images of Politicians

Roger D. Masters

Dartmouth College

Ethological Politics

Glendon Schubert

University of Hawaii-Manoa

Toward a Veterinarian Theory for a Crowded Planet

Lionel Tiger

Harry Frank Guggenheim

Foundation

\section{Discussant:}

John Wahlke

University of Arizona

\section{Report from the Committee for Liaison with the American Association for the Advancement of Science}

The Association for Politics and the Life Sciences hopes to develop relations between social and natural scientists with a common interest in the implications of contemporary biology for understanding political behavior and formulating public policies. At the 1982 meeting of the American Association for the Ad-
The Association for Politics and the Life Sciences hopes to pursue the possibility of a more formal relationship with the AAAS. In addition, we would like to organize another symposium at the 1983 meeting of AAAS. Suggestions for symposium topics or papers suited to AAAS format should be directed to Albert Somit, Office of the President, Southern Illinois University, Carbondale; Illinois 62901 or Professor Roger Masters, Department of Government, Dartmouth College, Hanover, N.H. 03755.

Roger Masters Dartmouth College

\section{Report from the Committee for Llaison with the International Political Science Association}

After almost a year of preliminary discussions, the IPSA Biology and Politics Research Committee was invited by the (then) Polish government to hold a special meeting on biological approaches to political behavior in Warsaw in June 1981. The purposes of the meeting were to plan for the 1982 IPSA Congress session and to familiarize Polish and European social scientists with recent developments in this general research area via a series of lectures and symposia. Unfortunately, the deteriorating political situation in Poland forced the cancellation of the meeting.

With the Warsaw meeting cancelled, planning for the 1982 Congress (scheduled August 9-14 in Rio de Janiero) was accomplished through smaller meetings in Europe and the U.S., numerous phone calls, and a rather extensive exchange of letters. With the close cooperation of the Center for Biopolitical Research, invitations to submit proposals for panel papers were mailed to several hundred political and social scientists. As has been the experience in the past, more proposals were submitted than could be accomodated by the IPSA rule fixing a maximum of six papers for the two sessions (morning and afternoon) allocated to the committee. A subset of the committee has been functioning as a review group to select the six papers, a task complicated by the fact that at the time this report is being written, some of those whose papers were approved are still uncertain as to whether they will be able to secure funding to attend the congress.

The committee is already planning a major conference for 1983 at which it will be possible to deal with developments in biopolitics more thoroughly and systematically than is practicable at the two- and three-hour panel sessions permitted at the meetings of our professional political science associations, whether international, national, or regional. Possible sites currently being explored are Italy, Germany, and, perhaps least likely now, Poland. A European site is desired to en- 